\title{
Molecular quantitation of H9N2 avian influenza virus in various organs of broiler chickens using TaqMan real time PCR
}

\author{
Najmeh Mosleh ${ }^{1}$, Habibollah Dadras ${ }^{2, *}$ and Ali Mohammadi ${ }^{3}$ \\ ${ }^{1}$ Group of Veterinary Medicine, Yasouj Branch, Islamic Azad University (IAU), Yasouj, presently postgraduate student \\ of Avian Medicine, School of Veterinary Medicine, Shiraz University, Shiraz, Iran, ${ }^{2}$ Department of Avian Medicine, \\ ${ }^{3}$ Department of Pathobiology, School of Veterinary Medicine, Shiraz University, Shiraz, Iran
}

*Correspondence to: Habibollah Dadras, Email: dadras@shirazu.ac.ir, Tel: +98 917 1129398, Fax: +98 7112286940

Received 05 September 2008, Revised 07 December 2008, Accepted 10 December 2008, Published online 16 January 2009

J Mol Genet Med (2009), 3(1), 152-157

(C) Copyright The Authors: This is an open access article, published under the terms of the Creative Commons Attribution Non-Commercial License (http://creativecommons.org/licenses/by-nc/2.0/uk/). This license permits noncommercial use, distribution and reproduction of the article, provided the original work is appropriately acknowledged with correct citation details.

\begin{abstract}
During the past decade, H9N2 low pathogenic avian influenza virus (LPAI) has caused considerable economic loss due to decreased production, increased mortality and the cost of vaccination in Iranian poultry industry. Because of widespread occurrence of this disease and the virus potential to mutate to highlypathogenic (HP) form and transmission to humans, it is, therefore, imperative to understand the pathogenesis and properties of these viruses. In this study, a two step TaqMan real time PCR assay was performed for the quantitation of $\mathrm{A} /$ chicken/Iran/772/1998 $\left(\mathrm{H}_{9} \mathrm{~N}_{2}\right)$ virus in various organs of broiler chickens at different days post inoculation (DPI). Forty 5-week-old commercial broiler chickens were inoculated with the virus. Five chickens were randomly selected on days 1, 3, 6 and 9 PI. Their trachea, lungs, spleen, kidneys, pancreas, blood and faeces were collected for virus detection. A PCR test was performed and the positive samples were used for quantitative real time PCR assay. The result of RT-PCR assay showed the presence of the virus in trachea $(40 \%, 33 \%)$, lungs $(20 \%, 66.6 \%)$ and spleen $(20 \%, 50 \%)$ of infected chickens on days 3 and 6 PI, respectively. The virus was also detected in the kidneys of inoculated chickens on $3(40 \%), 6(60 \%)$ and 9 $(100 \%)$ DPI. In faecal samples the virus was only detected on day 6 PI (83.3\%). The molecular quantitation of AIV showed that the AIV titre in the trachea, lungs and spleen of chickens at 3 DPI is lower than the AIV titre at 6 DPI in these organs. The highest titre was observed in the faeces. The AIV titre in all organs of the birds which died at 6 DPI was higher than those of the same organs in the other experimental birds.
\end{abstract}

KEYWORDS: Avian influenza, H9N2, virus quantitation, TaqMan real-time PCR

\section{INTRODUCTION}

Avian influenza $(\mathrm{AI})$ has been reported in many countries from the Middle East region and Asia (Alexander 2002, 2006). In 1998, an H9N2 subtype influenza A virus of low pathogenicity has been reported in the industrial poultry populations of Iran (Vasfi Marandi and Bozorgmehrifard, 1999) and thereafter it has caused outbreaks in commercial broiler chickens in Iran (Nili and Asasi, 2003). Outbreaks of H9N2 subtype also occurred in poultry in Pakistan (Naeem et al, 1999; Bano et al, 2003). Considerable economic loss due to decreased production, increased mortality and the cost of vaccination have occurred following H9N2 infection in Iranian poultry industry. H9N2 influenza viruses are also considered to be one of the potential candidates for the next human pandemic 
(Butt et al, 2005). Therefore, it is imperative to understand the pathogenesis and properties of these viruses.

It has been previously shown that real time PCR is a sensitive, specific and rapid test for diagnosis of influenza A viruses (Van Elden et al, 2000; Spackman et al, 2002 and 2003; Ellis et al, 2007). Quantitative real time PCR assay has also been used for quantitation of influenza A viruses (Lee and Suarez, 2004; Wards et al, 2004).

In the present study, a two-step real time PCR test, which uses TaqMan probe was performed for quantitation of H9N2 AI virus. We believe that the quantitation of the virus in different organs of the infected bird at different DPI may further help us to investigate the virus pathogenesis.

\section{MATERIALS AND METHODS}

\section{Challenge Virus}

All animal experiments were conducted according to local ethical guidelines, and were approved by the Animal Ethics Committee of the Veterinary School, Shiraz University, Iran. Avian influenza A virus, A/chicken /Iran/772/1998 $\left(\mathrm{H}_{9} \mathrm{~N}_{2}\right)$, which was obtained from Razi Vaccine and Serum Research Institute (Iran), passaged two times in 9 to 11-days old emberyonated chicken eggs and used as a challenge virus in this study. The embryo infective dose $\left(\mathrm{EID}_{50}\right)$ of infected allantoic fluid was calculated according to the Reed and Muench formula (1938). The virus was diluted 10 fold in sterile phosphate buffered saline (PBS) solution to obtain concentration of $10^{6.5} \mathrm{EID}_{50} / 100 \mu 1$.

\section{Birds}

Fifty one-day-old commercial broiler chicks were divided randomly into two groups (forty chicks in group 1 and ten chicks in group 2). They reared separately in an isolated room in Animal Research Unit of Veterinary School of Shiraz University. Feed and water were available ad libitum.

\section{Experimental design}

Prior to challenge all birds were serologicaly tested using hemagglutination inhibition test (HI) (Burleson et al, 1992). All birds were negative for antibodies to $\mathrm{H}_{9} \mathrm{~N}_{2}$ influenza virus. At the age of 35 days, all birds in the group 1 were challenged intranasally (IN) with $100 \mu 1$ allantoic fluid containing $10^{6.5} \mathrm{EID}_{50}$. The chickens in group 2 were kept as unchallenged controls. The chickens were monitored daily for 15 days to investigate the changes of antibody titre to H9N2 and mortality. On days 1, 3, 6 and 9 post inoculation (PI) five chickens from the group 1 and two chickens from the control group were randomly selected. Then, they were bled and sacrificed. The trachea, lungs, spleen, kidneys, pancreas and faeces were collected separately for virus detection and titration. Blood samples were collected in EDTA tubes. Sera of the birds were also collected at the same days and 15 DPI for HI test. All samples except blood, were immediately stored at $-70{ }^{\circ} \mathrm{C}$ until used.

\section{RNA isolation}

Immediately after collection of blood samples, RNA was isolated from $100 \mu 1$ of samples, using the $\mathrm{RNX}^{\mathrm{TM}}$ (-Plus) kit according to the manufacturer's instructions based on phenol-thiocyonate method (CinnaGen Inc, Iran). RNA was eluted in a final volume of $50 \mu 1$ distilled water (DW). All tissue samples were immediately frozen following collection and stored at $-70^{\circ} \mathrm{C}$ until used. Briefly, 10-100mg of tissue was homogenized and total RNA was isolated according to the Tissue RNA PrepMate ${ }^{\mathrm{TM}}$ kit (BioNeer Corporation, South Korea) protocol. RNA pellet was completely suspended in $50 \mu 1 \mathrm{DW}$. RNA was extracted from $140 \mu \mathrm{l}$ of the supernatants of $10 \%(\mathrm{w} / \mathrm{v})$ faecal suspensions using the QIAamp ${ }^{\mathbb{B}}$ Viral RNA kit (Qiagen, Germany) according to the manufacturer's protocol. Viral RNA was suspended in $60 \mu \mathrm{l}$ DW. RNA extracted from each sample was quantified by $A_{260 \mathrm{~nm}}$ spectrophotometry. Appropriate RNase Inhibitor and DNase (Fermentase) were added and stored at $-70^{\circ} \mathrm{C}$ until used.

\section{Conventional RT-PCR}

The cDNA was synthesized using AccuPowder ${ }^{\mathbb{R}}$ RT PreMix kit (BioNeer Corporation, South Korea) according to the manufacturer's protocol. The primers were specific for $\mathrm{H} 9$ protein gene (Table 1) and have been reported previously (Lee et al., 2001). Briefly, $5 \mu 1$ of total RNA and 20pmol of each $\mathrm{H} 9$-specific primers were used for cDNA preparation. PCR was performed as a screening test to amplify 488bp fragment of $\mathrm{H} 9$ protein gene of influenza $A$. The AccuPower PCR PreMix kit was used with a $20 \mu 1$ reaction mixture containig $1.5 \mathrm{mM} \mathrm{MgCl}_{2}, 30 \mathrm{mM} \mathrm{KCl}, 10 \mathrm{mM}$ tris$\mathrm{HCl}, 250 \mu \mathrm{M}$ (each) dNTP and 1U DNA Polymerase (BioNeer Corporation, South Korea). Five $\mu 1$ of cDNA and $10 \mathrm{pmol}$ of each primer were used. The reaction mixture was subjected to 35 cycles of $94^{\circ} \mathrm{C}, 53^{\circ} \mathrm{C}$ and $72^{\circ} \mathrm{C}$ each for $1 \mathrm{~min}$, followed by a final extension at $72^{\circ} \mathrm{C}$ for $10 \mathrm{~min}$ (Tajmanesh et al, 2006). The PCR products were resolved in $1 \%(\mathrm{w} / \mathrm{v})$ agarose gel containing ethidium bromide and visualized under UV illumination for image capture.

\section{Real time PCR}

The positive samples were used for molecular quantitation. The cDNA of positive samples was carried out using AccuPowder ${ }^{\circledR}$ RT PreMix kit (BioNeer Corporation, South Korea) according to the manufacturer's protocol. Reaction was performed with a mixture of $20 \mathrm{pmol}$ random hexamer and 20pmol of primer that was specific to a highly conserved region of matrix protein gene of influenza A virus (Table 1) and described previously by Ward et al (2004). The reaction mixture was incubated at $70^{\circ} \mathrm{C}$ for 5 min, then incubated at $42^{\circ} \mathrm{C}$ for $60 \mathrm{~min}$, heated to $95^{\circ} \mathrm{C}$ for $5 \mathrm{~min}$, cooled to $4^{\circ} \mathrm{C}$ then stored at $-70^{\circ} \mathrm{C}$ until used. The quantitative real-time PCR primers and TaqMan probe used in this study were described previously by Ward et al (2004) (Table 1). The primers amplified a 104bp fragment in the M1 gene of influenza A. The probe annealed to the part of the sequence amplified by two primers (Ward et al, 2004). The assays were performed on a 48 -well microtitre plate of BIO-RAD MiniOpticon ${ }^{\mathrm{TM}}$ System. The reaction mixture contained $5 \mu 1$ of target cDNA, $1 \mu 1$ of each primer at concentration of $10 \mathrm{pmol} / \mu 1,0.6 \mu 1$ of the TaqMan probe at concentration of $10 \mathrm{pmol} / \mu 1,2.5 \mu 1$ of dUTP mix, $2.4 \mu 1$ of $\mathrm{MgCl}_{2}$ at concentration of $50 \mathrm{mM}, 0.2 \mu \mathrm{l}$ of each Uracil DNA Glycosylase (UDG) and Taq polymerase enzyme, and $2 \mu 1$ of x10 buffer in a final volume of $20 \mu 1$. At first Uracil-N-Glycosylase (UNG) treatment at $50^{\circ} \mathrm{C}$ for $2 \mathrm{~min}$ 
and $\mathrm{UNG}$ inactivation at $95^{\circ} \mathrm{C}$ for $10 \mathrm{~min}$ was performed and then cDNA was amplified by 40 two step cycles $\left(15 \mathrm{sec}\right.$ at $95^{\circ} \mathrm{C}$ for denaturation of DNA, $1 \mathrm{~min}$ at $60^{\circ} \mathrm{C}$ for primer annealing and extension). Viral cDNA copy numbers (expressed as copies per $1 \mu \mathrm{g}$ total RNA) were quantified by comparison with a 10 -fold serially diluted plasmid standard of known concentration. The data and standard curves were obtained during target cDNA and recombinant plasmid amplification.

\section{Standard preparation}

RNA isolation from $100 \mu 1$ infected allantoic fluid was performed using the $\mathrm{RNX}^{\mathrm{TM}}$ (-Plus) kit and cDNA was carried out using BIONEER RT-premix kit according to the manufacture's instructions. PCR was performed to amplify 450bp fragment of matrix protein gene of influenza A that included the real time qPCR assay amplicons. The primer sequences are shown in Table 1. The BIONEER AccuPower PCR PreMix kit was used. The reaction mixture contained $10 \mu \mathrm{cDNA}$ and $20 \mathrm{pmol}$ of each primer in a final volume $20 \mu \mathrm{l}$ was subjected to $95^{\circ} \mathrm{C}$ for $5 \mathrm{~min}$ and 35 cycles of $95^{\circ} \mathrm{C}$ for $35 \mathrm{sec}, 54.9^{\circ} \mathrm{C}$ for $45 \mathrm{sec}, 72^{\circ} \mathrm{C}$ for $45 \mathrm{sec}$ and followed by final extension at $72^{\circ} \mathrm{C}$ for $5 \mathrm{~min}$. The PCR products were separated in a $1 \%$ $(\mathrm{w} / \mathrm{v})$ agarose gel and visualized under ultraviolet light after staining with ethidium bromide. PCR products (450bp) was cloned into a T-vector (pTZ57R/T) based on Fermentas InsTAclone ${ }^{\mathrm{TM}} \mathrm{PCR}$ cloning kit instructions. The plasmid DNA was amplified in E. coli strain XL1-blue and purified using BIONEER Accuprep Plasmid Extraction kit. The recombinant plasmid was verified by DNA sequencing. The concentration of the plasmid DNA was calculated with a spectrophotometer. Recombinant plasmids were serially diluted 10 -fold as a standard in the quantitative real-time PCR.

\section{RESULTS}

\section{RT-PCR results}

The presence of the virus in various organs of the birds was determined by RT-PCR. The virus was detected in trachea $(40 \%, 33 \%)$, lung $(20 \%, 66.6 \%)$ and spleen $(20 \%, 50 \%)$ of infected chickens on days 3 and 6 PI, respectively. The virus was also detected in kidneys of inoculated chickens on days $3(40 \%), 6(60 \%)$ and $9(100 \%)$ PI. In fecal samples the virus was only detected on day 6 PI $(83.3 \%)$. We did not detect the virus on 1 DPI and also in all pancreas and blood samples. The frequencies of virus recovery were $50 \%$ for kidney tissues, $22.7 \%$ for lung tissues and faeces, $18 \%$ for spleen and tracheal tissues (Table 2).

On days 2 and 6 PI two inoculated chickens died. All organs of the bird died on day 2 PI were negative for viral RNA detection except the kidneys but viral RNA was recovered from the trachea, lungs, spleen and faeces of the bird died on day 6 PI. No virus was detected in any tissue of the uninfected control group.

\section{HI test results}

As shown in Table 2, the antibody titre was increased at 6 DPI and reached to $2^{-9}(\log 2)$ at 15 DPI in the experimental group. There was no serological evidence of AIV infection in control group.

\section{Real-time PCR results}

The qRT-PCR was performed to quantify the titre and variations in AIV RNA levels over time in various tissues of chickens infected experimentally. AIV RNA levels were highest in faeces, trachea and lung of the bird died on day 6 post inoculation, respectively. By the way, the highest titre was observed in the faeces of sampled birds. The mean of viral copies per $1 \mu \mathrm{g}$ total RNA in trachea at 3 DPI was 22660 . The viral load continued to increase in trachea at 6 DPI (143000 in sampled bird and 10700000 in dead bird). The mean of AIV RNA levels in lung were 37900 at 3 DPI and 133805 at 6 DPI. In the lung of the dead bird the level of AIV was 1520000 copies per $1 \mu \mathrm{g}$ total RNA. AIV RNA level in spleen tissue at 3 DPI was 710 copies per $1 \mu \mathrm{g}$ total RNA. The mean of viral copies per $1 \mu \mathrm{g}$ total RNA in spleen at 6 DPI was 6787.5. The molecular quantitation of AIV showed that the AIV titre in the trachea, lung and spleen of chickens at 3 DPI is lower than the AIV titre at 6 DPI in these organs. However, AIV RNA levels were dropped at 9 DPI and the virus was not detected in these organs. Although the most frequent detection of the virus was in the kidneys, the lowest titre was observed in this organ.

\section{DISCUSSION}

Over recent years, real-time PCR has increasingly been used for pathogenic detections due to its rapidity, simplicity, sensitivity, specificity and ability to quantify infection levels (Edwards et al., 2004). Real-time RT-PCR assays have also been developed to detect and quantify AIV (Spackman et al. 2002, 2003; Lee and Suarez 2004; Cattoli et al. 2004). To investigate pathogenesis of $\mathrm{H}_{9} \mathrm{~N}_{2}$ low pathogenic avian influenza virus, a virus which is caused disease in domestic poultry in Iran, and the ability of this virus to replicate at different organs of broiler chickens, TaqMan real-time quantitative PCR assay was performed.

LPAI viruses produce infections that are localized to the respiratory and Gastrointestinal (GI) tracts of chickens (Swayne and Halvorson, 2003). Detection of the virus from trachea, lungs and kidneys indicates that $\mathrm{H}_{9} \mathrm{~N}_{2}$ AI virus is pneumotropic and nephrotropic following IN inoculation.

We observed predominant infection in the respiratory tract at days 3 and 6 PI. In the current study, The highest frequency of viral RNA detection in the trachea was observed at 3 DPI $(40 \%)$ and in the lung on day 6 PI (66.6\%). Comparison of AIV RNA levels at 3 and 6 DPI showed increasing titre of virus in the trachea and lung at 6 DPI. The virus was not detected at 9 DPI.

In the urinary tract predominant infection was observed between days 3 and 9 PI. The frequency of virus recovery was generally higher for kidney tissues. All kidneys sampled on day 1 PI lacked the viral RNA but viral RNA was identified on days 2, 3, 6 and 9 PI. We recovered the viral RNA from all of the kidney samples $(100 \%)$ on day 9 PI. These data indicate that $\mathrm{H}_{9} \mathrm{~N}_{2}$ has nephrotropic properties as indicated by Slemons and Swayne, 1995a,b; Slemons and Swayne, 1992a,b; Shalaby et al, 1994; Swayne and Slemons, 1994; Swayne and Slemons, 1990. Presumably, virus presentation in the kidneys had resulted 
Table 1: RT-PCR and real-time PCR primer and probe sequences

\begin{tabular}{|c|c|c|}
\hline Specificity & Primer/Probe & Sequence \\
\hline \multirow{2}{*}{ Avian influenza $\mathrm{H}_{9}$} & Forward & 5' CTY CAC ACA GAR CAC AAT GG 3' \\
\cline { 2 - 3 } & Reverse & $5^{\prime}$ GTC ACA CTT GTT GTR TC 3' \\
\hline cDNA synthesis \\
Influenza A
\end{tabular}

Table 2. Virus detection and molecular quantitation of $\mathrm{H}_{9} \mathrm{~N}_{2}$ AIV in the organs of experimentally infected broiler chicks at different days post inoculation plus mortality \& HI antibody titre

\begin{tabular}{|c|c|c|c|c|c|c|c|c|c|}
\hline \multirow{2}{*}{ 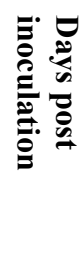 } & \multicolumn{7}{|c|}{ Samples } & \multirow{2}{*}{$\frac{3}{\frac{3}{2}}$} & \multirow{2}{*}{ 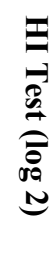 } \\
\hline & 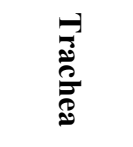 & $\stackrel{5}{\Xi}$ & 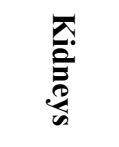 & $\frac{\mathscr{N}}{\frac{\pi}{D}}$ & 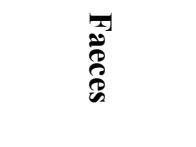 & 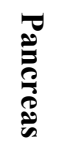 & $\frac{\sigma}{\grave{\Xi}}$ & & \\
\hline 1 & $0 / 5^{\mathrm{a}}$ & $0 / 5$ & $0 / 5$ & $0 / 5$ & $0 / 5$ & $0 / 5$ & $0 / 5$ & $0 / 40^{\mathrm{b}}$ & 2 \\
\hline $2 *$ & $0 / 1$ & $0 / 1$ & $\begin{array}{c}1 / 1 \\
(657)\end{array}$ & $0 / 1$ & $0 / 1$ & $0 / 1$ & - & $1 / 35$ & - \\
\hline 3 & $\begin{array}{c}2 / 5 \\
(22660)^{\mathrm{c}}\end{array}$ & $\begin{array}{c}1 / 5 \\
\left(3.79 \times 10^{4}\right)\end{array}$ & $\begin{array}{c}2 / 5 \\
(439)\end{array}$ & $\begin{array}{c}1 / 5 \\
(710) \\
\end{array}$ & $0 / 5$ & $0 / 5$ & $0 / 5$ & $0 / 34$ & 2 \\
\hline 6 & $\begin{array}{c}1 / 5 \\
\left(1.43 \times 10^{5}\right)\end{array}$ & $\begin{array}{c}3 / 5 \\
(133805)\end{array}$ & $\begin{array}{c}3 / 5 \\
(377.2)\end{array}$ & $\begin{array}{c}2 / 5 \\
(6787.5)\end{array}$ & $\begin{array}{c}4 / 5 \\
(2216840.75)\end{array}$ & $0 / 5$ & $0 / 5$ & $0 / 29$ & 4 \\
\hline $6^{*}$ & $\begin{array}{c}1 / 1 \\
\left(1.07 \times 10^{7}\right) \\
\end{array}$ & $\begin{array}{c}1 / 1 \\
\left(1.52 \times 10^{6}\right) \\
\end{array}$ & $0 / 1$ & $\begin{array}{c}1 / 1 \\
(18816) \\
\end{array}$ & $\begin{array}{c}1 / 1 \\
\left(6.66 \times 10^{8}\right) \\
\end{array}$ & $0 / 1$ & - & $1 / 29$ & - \\
\hline 9 & $0 / 5$ & $0 / 5$ & $\begin{array}{c}5 / 5 \\
(735.2)\end{array}$ & $0 / 5$ & $0 / 5$ & $0 / 5$ & $0 / 5$ & $0 / 23$ & 8 \\
\hline
\end{tabular}

$\mathrm{E}=$ Experimental group

* = Dead bird

${ }^{\mathrm{a}}$ No. of samples positive for virus recovery/total samples

${ }^{\mathrm{b}}$ No. of chicken/total

c Mean of positive samples

from a localized infection of the respiratory tract. The be necessary to continue the sample collection from the respiratory tract can allow communication and kidney for a longer time to evaluate the persistence of the transportation of infectious agents from outside of the virus in this organ.

body into the coelomic cavity (Shalaby et al.,

1994).Comparison of detection of the virus from the Hablolvarid et al. (2003) identified nucleoproteins of kidneys and the other organs showed that the virus detect $\mathrm{A} /$ Chicken/Iran/259/1998 $\left(\mathrm{H}_{9} \mathrm{~N}_{2}\right)$ isolate in the kidney and from the kidneys for a longer time. It seems that it would pancreas of 5-week-old chickens following intravenous 
(IV) inoculation, using immunohistochemical technique. Positive immunoreaction to AIV antigen and pathological changes, have been reported in the pancreas of chicks inoculated with $\mathrm{H}_{5} \mathrm{~N}_{3}$ (Shinya et al., 1995). However, in this study we did not recover the viral RNA in pancreas following IN inoculation. It seems that IV challenge is necessary for LPAI viruses to distribute in pancreas.

Detection of viral RNA from the spleen on day 3 and 6 PI may be due to a transient viremia. Therefore, detection of viral antigens in the kidneys may also have resulted from transient viremia. It has been reported that $\mathrm{H}_{9} \mathrm{~N}_{2}$ LPAI virus was detected and recovered from kidneys and spleen of experimentally infected chickens (Lee et al., 2007; Kown et al., 2008).

Viral RNA was not present in the blood of inoculated chickens. Other researchers did not find LPAI viruses in the blood of infected chickens too (Kown et al., 2008; Swayne and Beck, 2005). ). It seems that more frequent sampling from blood is necessary to investigate the hematogenic spread of $\mathrm{H}_{9} \mathrm{~N}_{2}$ virus.

The virus was detected in faeces only on day 6 PI. Kown et al. (2008) found $\mathrm{H}_{9} \mathrm{~N}_{2}$ antigen in cloacal swabs following IN inoculation on days 5 and 7 PI. Presence of the virus in faeces may have resulted from replication of the virus in GI tract. High AIV RNA levels in faeces at 6 DPI showed high replication of AIV in GI tract.

\section{CONCLUSIONS}

- The data indicated that maximal detection of the virus in different organs were on day 6 PI.

- The virus has pneumotropic and nephrotropic properties

- Detection of $\mathrm{H}_{9} \mathrm{~N}_{2}$ in spleen may be resulted from hematogenic spread of this virus.

- The $\mathrm{H}_{9} \mathrm{~N}_{2}$ virus persists in the kidneys for longer time than the other organs.

- The highest and lowest titre of the AIV was observed in the faeces and kidneys, respectively.

- The AIV titre in all organs of the birds died at 6 DPI were higher than those of the same organs in the other experimental birds.

- AIV RNA levels in the trachea, lung and spleen of infected chickens at 3 DPI was lower than the AIV RNA levels at 6 DPI in these organ.

\section{ACKNOWLEDGEMENTS}

This research was financially supported by Shiraz University Research Council

\section{COMPETING INTERESTS}

None declared.

\section{REFERENCES}

Alexander DJ. 2002. Report on avian influenza in the Eastern Hemisphere during 1997-2002, Avian Dis. 47, 792-797.

Alexander DJ. 2006. Summary of avian influenza activity in Europe, Asia, Africa and Australasia 2002-2006, Avian Dis, 51, 161-166.

Burleson FG, Chambers TM and Wiedbrauk DL. 1992 Virology: A Laboratory Manual, London, Academic press, Inc.

Bano S, Naeem K and Malik SA. 2003. Evaluation of pathogenic potential of avian influenza virus serotype $\mathrm{H}_{9} \mathrm{~N}_{2}$ in chickens, Avian Dis, 47 (3 Suppl), 817-822.

Butt KM , Smith GJ, Chen $\mathrm{H}$ et al. 2005. Human infection with an avian $\mathrm{H}_{9} \mathrm{~N}_{2}$ influenza A virus in Hong Kong in 2003, J Clin Microbiol, 43, 5760-5767.

Cattoli G, Drago A and Maniero S et al. 2004. Comparision of three rapid detection systems for type A influenza virus on tracheal swabs of experimentally and naturally infected birds, Avian Pathol, 33, 432-437.

Edwards K, Logan J and Saunders N (Eds ) 2004. Real-time PCR: an essential guide, Horizon Bioscience, Norfolk, UK, p, 346.

Ellis JS, Smith JW and Braham S et al. 2007.Design and validation of an $\mathrm{H}_{5}$ TaqMan real-time one step reverse transcriptase-PCR and confirmatory assays for diagnosis and verification of influenza A virus $\mathrm{H}_{5}$ infections in humans, J Clin Microbiol, 45, 1535-1543.

Hablolvarid MH, Sohraby Haghdost I, Pourbakhsh SA and Gholami MR 2003. A study on histopathologic changes in chicken following intravenous inoculation with avian influenza virus A/Chicken/Iran/259/1998(H9N2). Arch. Razi Ins, 55, 41-54.

Kwon JS ,Lee HJ and Lee DH et al. 2008. Immune responses and pathogenesis in immunocompromised chickens in response to infection with $\mathrm{H}_{9} \mathrm{~N}_{2}$ low pathogenic avian influenza virus. Virus Res, 133, 187-194.

Lee MS, Chang PC, Shien JH, Cheng MC and Shien HK. 2001. Identification and subtype of avian influenza viruses by reverse transcription-PCR. J Virol Methods, 97, 13-22.

Lee YJ, Shin JY and Song MS et al. 2007. Continuing evolution of $\mathrm{H}_{9}$ influenza viruses in Korean poultry, Virology, 359(2), 313-323.

Lee CW and Suarez DL. 2004. Application of real-time RTPCR for the quantitation and competitive replication study of H5 and H7 subtype avian influenza virus, J Virol Methods, $119,151-158$

Naeem K, Ullah A, Manvell RJ and Alexander DJ. 1999. Avian influenza A subtype $\mathrm{H}_{9} \mathrm{~N}_{2}$ in poultry in Pakistan. Vet Rec, 145, 560

Nili $\mathrm{H}$ and Asasi K. 2003. Avian influenza $\left(\mathrm{H}_{9} \mathrm{~N}_{2}\right)$ outbreak in Iran, Avian Dis, 47, 828-831.

Reed LJ and Muench H. 1938. A simple method of estimating fifty percent endpoint, Am J Hyg, 27, 493-497

Shalaby AA, slemons RD and Swayne DE. 1994. Pathological studies of A/Chicken/Alabama/7395/75(H4N8) influenza virus in specific pathogen free laying hens, Avian Dis, 38, 22 -32.

Shinya K, Awakura A, Shimada A, Silvano FD, Umemura T and Otsuka K. 1995. Pathogenesis of pancreatic atrophy by avian influenza A virus infection. Avian Pathol, 24, 623-632.

Slemons RD and Swayne DE. 1992a. Nephrotropic properties demonstrated by $\mathrm{A} /$ Chicken/Alabama/75 $\left(\mathrm{H}_{4} \mathrm{~N}_{8}\right)$ following intravenous challenge of chickens, Avian Dis, 36, 926-931.

Slemons RD and Swayne DE. 1995a, Tissue tropism and replicative properties of water fowl-origin influenza viruses in chickens, Avian Dis, 39, 521-527.

Spackman E , Senne DA and Bulaga LL et al. 2003. Development of real-time RT-PCR for the detection of avian influenza virus, Avian Dis, 47, 1079-1082.

Spackman E, Senne DA and Myers TJ et al. 2002. Development of a real-time reverse transcriptase PCR assay for type A 
influenza virus and the avian $\mathrm{H}_{5}$ and $\mathrm{H}_{7}$ hemagglutinin subtypes, J Clin Microbiol, 40, 3256-3260.

Swayne DE and Beck JR. 2005. Experimental study to determine if low-pathogenicity and high-pathogenicity avian influenza viruses can be present in chicken breast and thigh meat following intranasal virus inoculation, Avian Dis, 49, 81-85.

Swayne DE and Halvorson DA. 2003. Influenza. In: Saif YM, Barnes HJ, Fadly AM, Glisson JR, McDougald LR and Swayne DE (Eds). Disease of Poultry, Ames, Iowa, Iowa State University Press. $11^{\text {th }}$ Edn, pp, 135-160.

Swayne DE and Slemons RD. 1995b. Comparative pathology of intravenously inoculated wild duck and turkey origin type A influenza virus in chickens, Avian Dis, 39, 74-84.

Swayne DE and Slemons RD. 1994. Comparative pathology of a chicken origin and two duck origin influenza virus isolated in chickens, the effect of rout of inoculation, Vet Pathol, 31, 237-245.

Swayne DE and Slemons RD. 1992b, Evaluation of the kidney as a potential site of avian influenza virus persistence in chickens, Avian Path, 36, 937-944
Swayne DE and Slemons RD. 1990. Renal pathology in specificpathogen-free chickens with a water fowl-origin type A influenza virus, Avian Dis, 34, 285-297.

Tajmanesh S, Toroghi R, Momayez R and Pourbakhsh SA. 2006. Establishment of RT-PCR for detection of avian influenza virus (H9N2) in field cases compared to virus isolation method, Arch Razi Ins, 61, 111-116.

Van Elden LJR, Nijhuis M, Schipper P, Schuurman R and Van Loon AM. 2000. Simultaneous detection of influenza viruses A and B using real-time quantitative PCR, J Clin Microbiol, 39, 196-200.

Vasfi Marandi M and Bozorgmehrifard MH. 1999. An outbreak of non-highly pathogenic avian influenza in chickens in Iran, In: Proc. $61^{\text {st }}$ meeting of World Veterinary Association. France, CD-ROM.

Ward CL, Dempsey ML and Ring CJA et al. 2004. Design and performance testing of quantitative real time PCR assays for influenza A and B viral load measurement, J Clin Virol, 29, 179-188. 